\title{
Changes in Contraceptive Method Mix In Developing Countries
}

CONTEXT: Understanding shifts in contraceptive method mix is key to helping policymakers, program managers and donor agencies meet current contraceptive demand and estimate future needs in developing countries.

METHODS: Data from Demographic and Health Surveys, Reproductive Health Surveys and other nationally representative surveys were analyzed to describe trends and shifts in method mix among married women of reproductive age from 1980 to 2005. The analysis included 310 surveys from 104 developing countries.

RESULTS: Contraceptive use among married women of reproductive age increased in all regions of the developing world, reaching 66\% in Asia and $73 \%$ in Latin America and the Caribbean in 2000-2005, though only 22\% in SubSaharan Africa. The proportion of married contraceptive users relying on the IUD declined from $24 \%$ to $20 \%$, and the proportion using the pill fell from $16 \%$ to $12 \%$. The share of method mix for injectables rose from $2 \%$ to $8 \%$, and climbed from $8 \%$ to $26 \%$ in Sub-Saharan Africa, while the share for condoms was 5-7\%. The overall proportion of users relying on female sterilization ranged from $29 \%$ to $39 \%$, reaching $42-43 \%$ in Asia and in Latin America and the Caribbean in 2000-2005; on average, the share of all method use accounted for by male sterilization remained below $3 \%$ for all periods. Use of traditional methods declined in all regions; the sharpest drop-from $56 \%$ to $31 \%$ of usersoccurred in Sub-Saharan Africa.

CONCLUSIONS: To meet the rising demand for modern methods, it is critical that future programmatic efforts provide methods that are both accessible and acceptable to users.

International Family Planning Perspectives, 2007, 33(3):117-123

Contraceptive prevalence-generally defined as the proportion of women of reproductive age using a contraceptive method-is one yardstick by which countries evaluate their family planning programs. Prevalence among married women has risen steadily in most developing countries over the past four decades. In developing countries overall, it climbed from $9 \%$ in the early 1960 s to $60 \%$ by the late 1990s. ${ }^{1}$

Contraceptive preferences and the promotion of different methods vary by region and country; therefore, so does the contraceptive method mix, or the share of use represented by each method. For example, female sterilization is the most widely employed method in developing countries, followed by the IUD, the pill and injectables. ${ }^{2}$ However, female sterilization is little used in the Near East, North Africa or Sub-Saharan Africa. ${ }^{1}$ One-third of developing countries have a very skewed method mix, in which a single method accounts for more than half of contraceptive use. ${ }^{3}$ Mature family planning programs, such as that of Paraguay, have a more balanced distribution of methods. ${ }^{4}$

Earlier studies have examined trends in contraceptive prevalence $^{5}$ and method mix. ${ }^{6}$ This study updates information on trends in method mix, using nationally representative survey data collected between 1980 and 2005. It also looks at trends in condom use among married women in developing countries in which HIV and AIDS are most prevalent. In addition, this study considers explanations for the observed changes in method mix over time and explores the potential public health impact and programmatic implications of these trends.

\section{METHODS}

The data in this article are from the Demographic and Health Survey series, directed by Macro International; the Reproductive Health Survey series, conducted by the U.S. Centers for Disease Control and Prevention; and other nationally representative surveys.

We identified 104 countries that have had at least one nationally representative survey measuring contraceptive use among married women of reproductive age; overall, data from 310 surveys were included in the analyses (Appendix Table 1, page 123). Seventy-two countries have had at least two surveys since 1980, including 28 from Sub-Saharan Africa, 17 from Latin America or the Caribbean, 15 from East, South or Southeast Asia (hereafter referred to as Asia), and 12 from other regions (North Africa, Europe, or Western or Central Asia).

We originally classified contraceptive methods into eight types: IUD, pill, injectable, condom, male sterilization, female sterilization, traditional methods and other (primarily vaginal methods). The lactational amenorrhea method appeared as a separate method beginning in 1999, and was
ByEric E. Seiber,

Jane T. Bertrand and Tara $M$.

Sullivan

Eric E. Seiber is assistant professor, Division of Health Services Management and Policy, Ohio State University-College of Public Health, Columbus, $\mathrm{OH}$, USA Jane T. Bertrand is director, and Tara $M$ Sullivan is research associate-both at the Center for Communication Programs, Johns Hopkins Bloomberg School of Public Health, Baltimore, MD, USA. 
classified as a traditional method. The implant was listed separately in a few surveys, and was included in the "other" category. Because the "other" category accounted for only $1 \%$ of contraceptive use in all surveys combined, we omitted it from analysis. We classified the remaining seven methods into three categories: reversible modern methods (IUD, pill, injectable and condom), permanent methods (male and female sterilization) and traditional methods (rhythm, withdrawal and folk methods).

One challenge in designing this analysis stemmed from the varying frequency of contraceptive prevalence surveys. The median interval between surveys was five years. However, 32 countries had had only a single survey over the 26year period, whereas one country (Egypt) had had 11 surveys. Another complication was that no nationally representative surveys were available for the former Eastern bloc countries until the entry of Western donors in the early 1990s. These variations are problematic for developing country estimates, because the resulting assessments depend on the available data for a particular period. For annual analyses of contraceptive prevalence, both the United Nations Population Fund and the Population Reference Bureau use the most recent data from each country. We used a variation of this technique for our analysis of changes over time.

We compiled average values for each country for five time periods: 1980-1984, 1985-1989, 1990-1994, 1995-1999 and 2000-2005. Periods without a survey were assigned the value of the previous period; for countries with only one survey in 26 years, all periods were assigned the same value. Exclusion of countries without recent surveys or with a single survey would have introduced volatility into the regional estimates that was attributable only to changes in survey frequency. Such volatility would have been most pronounced for the former Eastern bloc countries, as surveys in these countries were first conducted well into the 26-year study period. Applying these values to earlier periods prevents jumps in the regional and overall estimates caused solely by the addition of such countries to the trend analysis.

The 104 countries included represent $80 \%$ of the world's population. ${ }^{7}$ We weighted the data on the basis of the population of women of reproductive age, so that the contraceptive prevalence trends are representative for the developing world (excluding countries with no data).

Countries with an active family planning program are more likely than others to conduct contraceptive prevalence studies or Demographic and Health Surveys, and this difference biases prevalence estimates upward. Thus, con-

\begin{tabular}{|c|c|c|c|c|c|}
\hline Period & All & $\begin{array}{l}\text { Latin } \\
\text { America/ } \\
\text { Caribbean }\end{array}$ & $\begin{array}{l}\text { Sub- } \\
\text { Saharan } \\
\text { Africa }\end{array}$ & Asia & Other \\
\hline 1980-1984 & 47.2 & 54.1 & 13.7 & 50.8 & 46.7 \\
\hline 1985-1989 & 51.6 & 57.6 & 14.1 & 56.5 & 49.3 \\
\hline 1990-1994 & 55.0 & 58.7 & 15.4 & 61.1 & 51.0 \\
\hline 1995-1999 & 58.6 & 69.5 & 19.7 & 64.2 & 52.4 \\
\hline 2000-2005 & 60.0 & 72.7 & 21.8 & 65.5 & 54.3 \\
\hline
\end{tabular}

traceptive prevalence was 47\% for 1980-1984 for countries included in our analysis, compared with 38\% for developing countries as of $1980 .{ }^{1}$ However, because we focus on shifts over time rather than absolute prevalence levels, this upward bias does not affect the analysis of trends.

With the spread of the HIV and AIDS epidemic, many government agencies promote the use of condoms, even among married couples, for both pregnancy and disease prevention. However, condoms were not a popular contraceptive method among married couples in developing countries before the AIDS epidemic, and many married men continue to object to using them-especially with their wives. To examine whether condom use has increased among married couples in countries with a generalized AIDS epidemic, we asked married women about their condom use. Because awareness of the AIDS epidemic was not widespread in the 1980s, we limited this part of the analysis to countries that had an HIV prevalence among adults of at least 5\% in 2003 and that had had two contraceptive prevalence surveys since 1990 (South Africa is the exception).

\section{RESULTS}

Contraceptive prevalence among married women has increased gradually in all regions of the developing world since 1980, rising to $60 \%$ for the period 2000-2005 (Table 1). Prevalence is currently highest in Latin America and the Caribbean (73\%) and Asia (66\%); these rates are followed distantly by that of Sub-Saharan Africa (22\%). However, this pattern masks dramatic variations by country within regions.

Of the 72 countries with at least two surveys since 1980, nearly all showed a monotonic increase in prevalence over time. Only three of these countries (4\%) experienced a period of "backsliding"-that is, a decrease of more than three percentage points between surveys (this cut-point was used because smaller differences could be attributable to sampling error). Rates dropped by four points in India between 1988 and 1993, by seven points in the Philippines between 1986 and 1988, and by eight points in Rwanda between 1992 and 2000 (not shown).

Even if a particular method's absolute prevalence increases, its share of the method mix may decline. The following analyses focus on shifts in method mix, and thus are based on married women using contraceptives, rather than on all married women.

The proportion of all use accounted for by the IUD decreased from $24 \%$ to $20 \%$ over the 26 -year period (Table 2). This decline was particularly marked in Asia during the 1980s, whereas the IUD's share of use increased steadily in countries categorized as "other" (Table 3). Similarly, the pill's share of the method mix dropped from 16\% to $12 \%$ over the entire period. Overall, the proportion of all users relying on the pill fell in all regions, but the most dramatic decline-from 31\% to 18\%-occurred in Latin America and the Caribbean, most notably between the periods 1980-1984 and 1990-1994.

The share of method mix accounted for by use of in- 
TABLE 2. Percentage of married female contraceptive users who reported use of selected reversible methods, by survey period

\begin{tabular}{lllll} 
Period & IUD & Pill & Injectable & Condom \\
\hline $1980-1984$ & 23.5 & 16.0 & 1.8 & 5.7 \\
$1985-1989$ & 21.1 & 13.8 & 2.9 & 6.0 \\
$1990-1994$ & 20.7 & 12.8 & 3.9 & 5.1 \\
$1995-1999$ & 20.8 & 12.6 & 5.6 & 6.2 \\
$2000-2005$ & 20.1 & 12.3 & 7.6 & 6.9
\end{tabular}

jectables rose from $2 \%$ to $8 \%$ over the study period, with small increases in Asia and in Latin America and the Caribbean. Notably, the share in Sub-Saharan Africa grew from 8\% to $26 \%$ over this period. The proportion of users relying on injectables climbed steadily in all but three countries in this region, and overtook the proportion using the pill in 14 of the 28 countries with multiple surveys (not shown).

\begin{tabular}{|c|c|c|c|c|}
\hline Method and period & $\begin{array}{l}\text { Latin } \\
\text { America/ } \\
\text { Caribbean }\end{array}$ & $\begin{array}{l}\text { Sub- } \\
\text { Saharan } \\
\text { Africa }\end{array}$ & Asia & Other \\
\hline \multicolumn{5}{|l|}{ IUD } \\
\hline 1980-1984 & 9.2 & 5.1 & 27.9 & 22.9 \\
\hline 1985-1989 & 10.9 & 4.7 & 24.0 & 26.1 \\
\hline 1990-1994 & 10.7 & 7.0 & 22.8 & 29.0 \\
\hline 1995-1999 & 11.0 & 5.7 & 22.9 & 30.0 \\
\hline 2000-2005 & 9.9 & 2.9 & 22.8 & 29.3 \\
\hline \multicolumn{5}{|l|}{ Pill } \\
\hline 1980-1984 & 31.4 & 19.3 & 11.8 & 27.8 \\
\hline 1985-1989 & 27.6 & 19.3 & 9.3 & 25.7 \\
\hline 1990-1994 & 19.5 & 23.7 & 8.2 & 25.2 \\
\hline 1995-1999 & 19.5 & 22.3 & 8.0 & 25.2 \\
\hline 2000-2005 & 18.1 & 18.6 & 8.2 & 25.8 \\
\hline \multicolumn{5}{|l|}{ Injectable } \\
\hline 1980-1984 & 3.5 & 8.1 & 0.9 & 0.6 \\
\hline 1985-1989 & 2.7 & 9.4 & 2.4 & 0.6 \\
\hline 1990-1994 & 2.8 & 12.2 & 3.3 & 0.6 \\
\hline 1995-1999 & 3.9 & 16.8 & 4.8 & 1.3 \\
\hline 2000-2005 & 6.3 & 25.7 & 5.8 & 2.2 \\
\hline \multicolumn{5}{|l|}{ Condom } \\
\hline 1980-1984 & 2.6 & 3.2 & 6.0 & 8.0 \\
\hline 1985-1989 & 3.2 & 2.8 & 6.5 & 8.3 \\
\hline 1990-1994 & 4.0 & 4.9 & 4.9 & 7.6 \\
\hline 1995-1999 & 6.1 & 6.2 & 5.9 & 7.8 \\
\hline 2000-2005 & 7.0 & 8.3 & 6.5 & 7.7 \\
\hline \multicolumn{5}{|l|}{ Male sterilization } \\
\hline 1980-1984 & 0.9 & $<0.1$ & 5.4 & 0.2 \\
\hline 1985-1989 & 1.1 & 0.3 & 6.5 & 0.2 \\
\hline 1990-1994 & 0.3 & 0.3 & 8.6 & 0.2 \\
\hline 1995-1999 & 2.1 & 0.4 & 5.8 & 0.2 \\
\hline 2000-2005 & 2.2 & 0.3 & 5.1 & 0.2 \\
\hline \multicolumn{5}{|l|}{ Female sterilization } \\
\hline 1980-1984 & 32.9 & 7.0 & 34.3 & 5.4 \\
\hline 1985-1989 & 35.8 & 7.1 & 42.5 & 5.6 \\
\hline 1990-1994 & 47.8 & 7.9 & 43.4 & 5.8 \\
\hline 1995-1999 & 43.4 & 7.9 & 43.1 & 6.1 \\
\hline 2000-2005 & 43.4 & 6.5 & 42.1 & 6.0 \\
\hline \multicolumn{5}{|l|}{ Traditional methods } \\
\hline 1980-1984 & 17.5 & 56.4 & 13.2 & 33.1 \\
\hline 1985-1989 & 17.5 & 55.4 & 8.6 & 32.0 \\
\hline 1990-1994 & 14.3 & 42.5 & 8.1 & 30.0 \\
\hline 1995-1999 & 13.4 & 39.4 & 8.3 & 27.8 \\
\hline 2000-2005 & 12.3 & 30.6 & 8.6 & 26.8 \\
\hline
\end{tabular}

The proportion of married female contraceptive users relying on condoms rose from $6 \%$ to $7 \%$ over the study period. In Latin America and the Caribbean, as well as in SubSaharan Africa, this proportion increased from 3\% in the early 1980 s to $7-8 \%$ in 2000-2005.

Women's reliance on male sterilization for contraception was low in all periods, with this method's share of use remaining below 3\% for all periods. In Asia, however, the proportion of users relying on vasectomies rose to $9 \%$ in 1990-1994, before dropping back to 5\% in 2000-2005. Three Asian countries reported periods of relatively high vasectomy use (not shown), but reliance on vasectomy declined as a proportion of method mix-from 9\% to 4\% in India (1993 to 1999), from 19\% to 16\% in Nepal (1996 to 2001 ) and from $8 \%$ to 6\% in Sri Lanka (1987 to 1993).

Female sterilization was the most widely used method of contraception in developing countries, and its share of the method mix ranged from $29 \%$ to $39 \%$ across the time periods (not shown). However, this pattern masks sharp regional variations. For the past 26 years, female sterilization has accounted for at least one-third of all contraceptive use in Asia and in Latin America and the Caribbean. Indeed, its share in the latter region peaked at $48 \%$ in 1990-1994, before declining slightly over the next decade. In Asia, the share of use accounted for by female sterilization rose from 34\% in 1980-1984 to plateau at 42-43\% from 1985 to 2005 . Because these values are weighted by population size, China and India-with large populations and high levels of female sterilization-exert a strong influence on these trends. In contrast, the share of female sterilization in the method mix remained fairly level at 5-8\% in Sub-Saharan Africa and in "other" countries.

The proportion of use accounted for by traditional methods varied widely by region. This proportion changed markedly over time in Sub-Saharan Africa. In surveys conducted in 1980-1984, 56\% of users in this region reported employing traditional methods; subsequently, however, the proportion declined to $31 \%$. Traditional methods represented a much smaller proportion of the method mix in Asia and in Latin America and the Caribbean, where it decreased from 13\% to $9 \%$ and from $18 \%$ to $12 \%$, respectively.

Eleven of the 12 countries with high HIV prevalence among adults are in Sub-Saharan Africa (Table 4, page 120). No more than $8 \%$ of married women in any country reported using condoms at the latest survey. Moreover, the proportion using condoms increased substantially in only two countries: In Cameroon, it rose from 2\% in 1998 to 8\% in 2004 (an average annual change of 0.9\%), and in Namibia, it rose from $0.3 \%$ in 1992 to 5\% in 2000 (an average annual change of $0.6 \%$ ). Even though HIV prevalence among adults in the other countries ranged from 5\% to $25 \%$, the level of condom use in these countries remained below $4 \%$.

\section{DISCUSSION}

While the overall increase in contraceptive prevalence and the replacement of traditional methods by more effective modern methods in developing countries are welcome 


\begin{tabular}{|c|c|c|c|c|}
\hline \multirow[t]{2}{*}{ Country } & \multirow{2}{*}{$\begin{array}{l}\% \text { of adults } \\
\text { with HIV, } \\
2003\end{array}$} & \multicolumn{3}{|c|}{$\%$ of married women reporting condom use } \\
\hline & & Earliest* & Most recent & $\begin{array}{l}\text { Average annual } \\
\% \text { change }\end{array}$ \\
\hline Cameroon & 6.9 & 2.1 (1998) & 7.6 (2004) & 0.9 \\
\hline Côte d'Ivoire & 7.0 & 0.7 (1994) & 1.8 (1999) & 0.2 \\
\hline Haiti & 5.6 & 2.6 (1995) & $2.9(2000)$ & 0.1 \\
\hline Kenya & 6.7 & 0.8 (1993) & $1.2(2003)$ & $<0.1$ \\
\hline Malawi & 14.2 & 1.6 (1992) & $1.8(2004)$ & $<0.1$ \\
\hline Namibia & 21.3 & 0.3 (1992) & $5.2(2000)$ & 0.6 \\
\hline Nigeria & 5.4 & 1.2 (1999) & 1.9 (2003) & 0.2 \\
\hline Rwanda & 5.1 & 0.2 (1992) & $0.4(2000)$ & $<0.1$ \\
\hline South Africa & 21.5 & 0.7 (1987) & 1.7 (1998) & $<0.1$ \\
\hline Tanzania & 8.8 & 1.7 (1994) & $2.0(2005)$ & $<0.1$ \\
\hline Zambia & 16.5 & 3.5 (1996) & 3.8 (2002) & 0.1 \\
\hline Zimbabwe & 24.6 & 2.3 (1994) & 1.8 (1999) & -0.1 \\
\hline
\end{tabular}

*Surveys conducted before 1990 were excluded because awareness of the AIDS epidemic was not widespread in the 1980s. South Africa's 1987 survey was the exception and was included because it was the closest survey to 1990 . Note: HIV prevalence of $5 \%$ or more was considered high.

trends, the relatively low use of condoms and the increasing popularity of injectables present unique challenges for family planning efforts and may have significant programmatic and public health implications in years to come, especially in Sub-Saharan Africa.

\section{Reduced Reliance on Traditional Methods}

One encouraging trend in developing countries is the increase in contraceptive prevalence concurrent with the decrease in the share of all use accounted for by traditional methods. Greater reliance on modern contraceptives carries well-known benefits for women, their families and society-lower levels of unintended pregnancy, unsafe abortion, and maternal and child morbidity and mortality, as well as a slowing of population growth.

The rising use of modern methods suggests that family planning programs have made significant progress in offering contraceptives that are both acceptable and accessible to users in developing countries. Improved access to contraceptives can strongly increase their uptake, as Ross et al. demonstrated in analyses based on data from the family planning program effort index and contraceptive prevalence surveys. ${ }^{5}$ Studies in Turkey ${ }^{8}$ and rural Kenya ${ }^{9}$ have shown that family planning programs that improve the availability of contraceptives lead to increases in the use of modern methods at the expense of traditional methods. To meet the rising demand for modern methods, program managers, donors and policymakers will need to work together to ensure an adequate stream of contraceptive supplies as the number of women of reproductive age continues to grow.

Although the replacement of traditional methods by modern methods is a positive trend, there is cause for concern when government policy primarily promotes the use of permanent and long-acting methods. For example, widespread use of female sterilization in India reflects a legacy of efforts to curb population growth through the use of targets. Despite a 1996 national population policy that eliminated the use of targets and called for the promotion of a wider variety of contraceptive choices, female sterilization continues to dominate India's method mix. ${ }^{10}$ Similarly, China's population policy has used incentives and disincentives to achieve demographic objectives, leading to disproportionate use of the IUD and female sterilization. ${ }^{11,12}$ In keeping with government policy, women with one child tend to use the IUD, while those with two or more children rely on female sterilization. $^{12,13}$

\section{Consistently Low Use of Condoms}

Condom use as a proportion of method mix has remained almost unchanged in developing countries, despite the global AIDS epidemic and efforts to promote the $A B C$ approach (abstinence, being faithful, condom use). The proportion of married female contraceptive users reporting condom use remained constant and low in all regions over the study period. Of the 12 countries with a 2003 HIV prevalence of at least 5\%, only Cameroon and Namibia have shown rising condom use among married women.

Worldwide, $80 \%$ of HIV infections are transmitted sexually, and another $10 \%$ during pregnancy, birth or breastfeeding. ${ }^{14}$ Although a joint position statement by the World Health Organization, the Joint United Nations Programme on HIV/AIDS and the United Nations Population Fund ${ }^{15}$ promoted the male latex condom as the most effective means of preventing sexual transmission, this study found little evidence that condoms are a popular method among married couples.

Low levels of condom use are cause for concern, particularly in the context of generalized epidemics such as those found in Sub-Saharan Africa. Despite a growing number of studies showing that an increased proportion of HIV infections are transmitted through sex within marriage or with a committed partner, ${ }^{16}$ individuals in committed relationships tend to resist condom use, because it is often considered a sign of infidelity. ${ }^{17}$ However, evidence from national surveys has shown that condom use is much more prevalent outside of marriage, among both married and unmarried men and women. ${ }^{18}$

In our study, the data may not accurately reflect total condom use among men, since men's use of condoms with extramarital sexual partners would not be picked up by surveys conducted among married women. ${ }^{19,20}$ Furthermore, the questions used in the surveys from which our data came did not ask whether condoms were being used for pregnancy or disease prevention, or both. (The question about condom use appeared in the survey section on contraception.)

Our results demonstrating continued low levels of condom use within marriage highlight the need for greater programmatic efforts to procure, promote and distribute condoms. They also point up the need to develop femalecontrolled methods that can protect women against unplanned pregnancy, HIV and other STIs.

\section{Increased Use of Injectables}

Another trend that is likely to have a significant public health impact is the remarkable increase in injectable use in SubSaharan Africa and in lower-income Latin American coun- 
tries. This dramatic rise signals regional shifts in method mix away from the pill and traditional methods. The injectable, a highly effective, long-lasting and reversible method that meets the needs of women who want to space rather than limit their births, is the leading method in a number of Sub-Saharan African countries. ${ }^{21}$

Injectables offer several benefits, including the reduced likelihood of unplanned pregnancy, unsafe abortion and maternal mortality. The rapid increase in injectable use is largely attributable to its widespread accessibility. ${ }^{2}$ Furthermore, women can use this method without others knowing about it; injections are administered periodically (once a month or every three months) and there are no supplies to keep on hand. One study estimated that 6-20\% of women in Sub-Saharan Africa used the injectable covertly, a practice that was more common in areas where contraceptive prevalence was low, particularly rural areas. ${ }^{22}$ Eventually, injectables may become even more convenient for women as availability increases through community-based distribution and pharmacies. ${ }^{2}$

\section{Conclusions}

The low level of condom use and the growing use of injectables in developing countries point to a critical public health issue; providing and supporting use of methods that are acceptable and accessible to women can reduce unintended pregnancy and save lives. Because of women's relative lack of decision-making power in developing countries, it makes sense to provide methods that are female-controlled and can be used covertly. In the future, procurement and distribution of contraceptive supplies will be challenging issues, given rising demand for modern contraceptives, increasing population size and shrinking resources for family planning programs.

\section{REFERENCES}

1. Population Reference Bureau, Family planning worldwide 2002 data sheet, Washington, DC: Population Reference Bureau, 2002.

2. Lande R and Richey C, Expanding services for injectables, Population Reports, 2006, Series K, No. 6.

3. Sullivan TM et al., Skewed contraceptive method mix: why it happens, why it matters, Journal of Biosocial Science, 2006, 38(4):501-521.

4. Centro Paraguayo de Estudios de Población (CEPEP), Encuesta Nacional de Demografia y Salud Sexual y Reproductiva, 2004, Informe Final, Asunción, Paraguay: CEPEP, 2005.

5. Ross J et al., Contraceptive method choice in developing countries, International Family Planning Perspectives, 2002, 28(1):32-40.

6. Johnson JT and Macke BA, Estimating contraceptive need from trends in method mix in developing countries, International Family Planning Perspectives, 1996, 22(3):92-96.

7. U.S. Bureau of the Census, International Data Base, 2005, <http://www.census.gov/ipc/www/idb>, accessed Aug. 17, 2007.

8. Aytekin NT et al., The comparison of reproductive health data in a rural district in Turkey (1981-2001), European Journal of Contraception and Reproductive Health Care, 2002, 7(4):234-237.

9. Magadi M and Curtis S, Trends and determinants of contraceptive method choice in Kenya, Studies in Family Planning, 2003, 34(3):149159

10. Donaldson PJ, The elimination of contraceptive acceptor targets and the evolution of population policy in India, Population Studies, 2002,
56(1):97-110.

11. David HP, Incentives, reproductive behavior, and integrated community development in Asia, Studies in Family Planning, 1982, 13(5): 159-173.

12. Bertrand JT et al., Skewed method mix: a measure of quality in family planning programs, working paper, Chapel Hill, NC, USA: MEASURE Evaluation Project, Carolina Population Center, University of North Carolina, 2000, No. 23.

13. Choe MK and Tsuya NO, Why do Chinese women practice contraception? the case of rural Jilin Province, Studies in Family Planning, 1991, 22(1):39-51.

14. UN Millennium Project, Public Choices, Private Decisions: Sexual and Reproductive Health and the Millennium Development Goals, New York: United Nations Development Programme, 2006.

15. World Health Organization, Joint United Nations Programme on HIV/AIDS and United Nations Population Fund, Position statement on condoms and HIV prevention, 2004, <http://www.unfpa.org/ upload/lib_pub_file/343_filename_Condom_statement.pdf>, accessed June 7, 2006 .

16. Sinding S, Does 'CNN' (condoms, needles, negotiation) work better than 'ABC' (abstinence, being faithful and condom use) in attacking the AIDS epidemic? International Family Planning Perspectives, 2005 , 31(1):38-40.

17. Maharaj P and Cleland J, Condom use within marital and cohabiting partnerships in KwaZulu-Natal, South Africa, Studies in Family Planning, 2004, 35(2):116-124.

18. Salem R and Gardner R, HIV/AIDS survey findings, supplement to Men's surveys: new findings, Population Reports, 2004, Series M, No. 18, <http://www.infoforhealth.org/pr/m18/hivaids/>, accessed May $22,2006$.

19. Salem R, Men's surveys: new findings, Population Reports, 2004, Series M, No. 18 .

20. Zlidar V et al., New survey findings: the reproductive revolution continues, Population Reports, 2003, Series M, No. 17.

21. Caldwell JC and Caldwell P, Africa: the new family planning frontier, Studies in Family Planning, 2002, 33(1):76-86.

22. Biddlecom A and Fapohunda BM, Covert contraceptive use: prevalence, motivations, and consequences, Studies in Family Planning, 1998, 29(4):360-372.

\section{RESUMEN}

Contexto: Comprender los cambios en la mezcla de métodos anticonceptivos es esencial para ayudar a las personas encargadas de formular las políticas, gerentes de programas y agencias donantes para satisfacer la actual demanda de anticonceptivos y estimar las necesidades futuras en los países en desarrollo.

Métodos: Datos de Encuestas Demográficas y de Salud, Encuestas de Salud Reproductiva y otras encuestas representativas a nivel nacional fueron analizados para describir tendencias y cambios en la mezcla de métodos entre las mujeres casadas en edad reproductiva, de 1980 a 2005. Este análisis incluyó 310 encuestas de 104 países en desarrollo.

Resultados: El uso de anticonceptivos aumentó en todas las regiones del mundo en desarrollo, llegando a 66\% de las mujeres casadas en edad reproductiva en Asia y 73\% en América Latina y el Caribe en 2000-2005, aunque solamente llegó a $22 \%$ en África subsahariana. La proporción del uso total que corresponde al DIU disminuyó de 24\% a 20\% con el tiempo, y la proporción que pertenece a la píldora bajó de $16 \%$ a 12\%. La proporción del uso que se debe a las inyecciones aumentó de 2\% a 8\% (y escaló de $8 \%$ al 26\% en África subsahariana). 
A nivel mundial, mientras que la proporción que corresponde a los condones permaneció en 5-7\% en todos los períodos, la que corresponde a la esterilización femenina oscilaba entre 29\% y 39\%, llegando a 42-43\% en Asia y América Latina y el Caribe en 2000-2005. En promedio, la proporción que representó la esterilización masculina en el uso de todos los métodos, se mantuvo por debajo del 3\% en todos los períodos estudiados. El uso de métodos tradicionales disminuyó a través del tiempo en todas las regiones; la caída más drástica-del 56\% del uso total al 31\%-ocurrió en África subsahariana.

Conclusiones: Para satisfacer la creciente demanda de mé- todos modernos, es crítico que los futuros esfuerzos programáticos proporcionen métodos que sean tanto accesibles como aceptables para las y los usuarios.

\section{RÉSUMÉ}

Contexte: Pour répondre à la demande contraceptive actuelle et estimer les besoins à venir des pays en développement, les décideurs politiques, gestionnaires de programmes et organismes donateurs doivent impérativement comprendre les variations de la répartition des méthodes contraceptives.

Méthodes: Les données des Enquêtes démographiques et de

\begin{tabular}{|c|c|c|c|}
\hline Country & Survey years & Country & Survey years \\
\hline \multicolumn{2}{|l|}{ Latin America/Caribbean } & \multicolumn{2}{|c|}{ Sub-Saharan Africa (continued) } \\
\hline Belize & 1991,1999 & Togo & 1988,1998 \\
\hline Bolivia & $1983,1989,1994,1998,2003$ & Uganda & $1988,1995,2001,2005$ \\
\hline Brazil & $1986,1991,1996$ & Zaire & 1991 \\
\hline Colombia & $1980,1986,1990,1995,2000$ & Zambia & $1992,1996,2002$ \\
\hline Costa Rica & $1981,1986,1993$ & Zimbabwe & $1984,1988,1994,1999$ \\
\hline Cuba & 1987 & & \\
\hline Dominican Republic & 1980, 1983, 1986, 1991, 1996, 1999, 2002 & Asia & \\
\hline Ecuador & $1982,1987,1989,1994,1999,2004$ & Bangladesh & 1989, 1991, 1994, 1997, 2000, 2004 \\
\hline El Salvador & $1985,1988,1993,1998,2003$ & Cambodia & 1995,2000 \\
\hline Guatemala & $1983,1987,1995,1999,2002$ & China & 1982, 1985, 1988, 1992, 1997, 2001 \\
\hline Haiti & $1983,1987,1989,1995,2000$ & Hong Kong & $1982,1987,1992$ \\
\hline Honduras & $1981,1984,1987,1996,2001$ & India & $1980,1988,1993,1999$ \\
\hline Jamaica & $1983,1989,1993,1997,2002$ & Indonesia & $1980,1985,1987,1991,1994,1997,2003$ \\
\hline Mexico & $1982,1987,1992,1995,1997,2003$ & Malaysia & 1984 \\
\hline Nicaragua & $1981,1993,1998,2001$ & Myanmar & 1991,1997 \\
\hline Panama & 1984 & Nepal & $1981,1986,1991,1996,2001$ \\
\hline Paraguay & 1987, 1990, 1996, 1998, 2004 & Pakistan & 1984,1991 \\
\hline Peru & $1981,1986,1992,1996,2000$ & Philippines & 1983, 1986, 1988, 1993, 1998, 2003 \\
\hline Puerto Rico & 1982,1996 & Singapore & 1982 \\
\hline \multirow[t]{2}{*}{ Trinidad and Tobago } & \multirow[t]{2}{*}{1987} & South Korea & $1982,1985,1988,1992,1994$ \\
\hline & & Sri Lanka & $1981,1982,1987,1993$ \\
\hline \multicolumn{2}{|l|}{ Sub-Saharan Africa } & Taiwan & $1980,1985,1991,1992$ \\
\hline Benin & 1981, 1996, 2001 & Thailand & 1980, 1981, 1984, 1987, 1993, 1996 \\
\hline Botswana & 1984,1988 & Vietnam & $1988,1994,1997,2002$ \\
\hline Burkina Faso & 1993, 1999, 2003 & & \\
\hline Burundi & 1987 & \multicolumn{2}{|l|}{ Other } \\
\hline Cameroon & $1991,1998,2004$ & Albania & 2002 \\
\hline Cape Verde & 1998 & Algeria & $1986,1992,1995$ \\
\hline Central African Republic & 1995 & Armenia & 2000 \\
\hline Chad & 1997 & Azerbaijan & 2001 \\
\hline Comoros & 1996 & Bahrain & 1995 \\
\hline Côte d'Ivoire & $1980,1994,1999$ & Czech Republic & 1993 \\
\hline Eritrea & 1995,2002 & \multirow[t]{2}{*}{ Egypt } & \multirow{2}{*}{$\begin{array}{l}\text { 1980, 1981, 1984, 1988, 1992, 1995, } \\
\text { 1997, 1998, 2000, 2003, } 2005\end{array}$} \\
\hline Ethiopia & $1990,2000,2005$ & & \\
\hline Gabon & 2000 & Georgia & 1999 \\
\hline Ghana & $1988,1993,1998,2003$ & Iran & 1992, 1994 \\
\hline Guinea & $1992,1995,2005$ & Iraq & 1989 \\
\hline Kenya & $1984,1989,1993,1998,2003$ & Jordan & $1983,1985,1990,1997,2002$ \\
\hline Lesotho & 1992 & Kazakhstan & 1995,1999 \\
\hline Liberia & 1986 & Kuwait & 1987,1996 \\
\hline Madagascar & $1992,1997,2004$ & Kyrgyzstan & 1997 \\
\hline Malawi & $1984,1992,1996,2000,2004$ & Libya & 1995 \\
\hline Mali & 1987, 1996, 2001 & Moldova & 1997 \\
\hline Mauritania & 1999,2001 & Morocco & 1980, 1983, 1987, 1992, 1995, 2004 \\
\hline Mauritius & 1985,1991 & Oman & 1988,1995 \\
\hline Mozambique & 1997,2003 & Qatar & 1998 \\
\hline Namibia & $1989,1992,2000$ & Romania & 1993,1999 \\
\hline Niger & 1992,1998 & Saudi Arabia & 1996 \\
\hline Nigeria & 1981, 1990, 1999, 2003 & Syria & 1993 \\
\hline Rwanda & $1983,1992,2000,2005$ & Tunisia & 1983,1988 \\
\hline Senegal & 1986, 1993, 1997, 1999, 2005 & Turkey & $1983,1988,1993,1998,2003$ \\
\hline South Africa & $1981,1987,1998$ & Turkmenistan & 2000 \\
\hline Sudan & $1989,1990,1993$ & Ukraine & 1999 \\
\hline Swaziland & 1988 & United Arab Emirates & 1995 \\
\hline \multirow{2}{*}{ Tanzania } & 1992, 1994, 1996, 1999, 2005 & Uzbekistan & 1996 \\
\hline & & Yemen & 1992,1997 \\
\hline
\end{tabular}


santé, Enquêtes de santé de la reproduction et autres enquêtes nationalement représentatives ont été analysées de manière à décrire les tendances et variations de la ventilation des de méthodes parmi les femmes mariées en âge de procréer, de 1980 à 2005. Les données de 310 enquêtes originaires de 104 pays en développement ont été analysées.

Résultats: La pratique contraceptive des femmes mariées en âge de procréer s'est accrue dans toutes les régions du monde en développement, atteignant 66\% en Asie et $73 \%$ en Amérique latine et Caraibes en 2000-2005, mais seulement 22\% en Afrique subsaharienne. La proportion d'utilisatrices mariées ayant recours au stérilet a baissé, de 24\% à 20\%, de même que celle des utilisatrices de la pilule, passée de 16\% à 12\%. La part de pratique globale représentée par les injectables s'est quant à elle accrue, de $2 \%$ à $8 \%$, passant de $8 \%$ à $26 \%$ en Afrique sub- saharienne, tandis que la part du préservatifétait de 5\% à 7\%. Au total, la proportion d'utilisatrices ayant recours à la stérilisation féminine se situe entre 29\% et 39\%, atteignant pourtant 42-43\% en Asie et en Amérique latine et Caraïbes en 2000-2005. En moyenne, la part de pratique globale représentée par la stérilisation masculine demeure inférieure à 3\% sur toutes les périodes. Le recours aux méthodes traditionnelles est en baisse dans toutes les régions, la plus forte chute-de 56\% à 31\% des utilisatrices-s'étant produite en Afrique subsaharienne.

Conclusions: Pour répondre à la demande grandissante de méthodes contraceptives modernes, il est crucial que les efforts programmatiques futurs se concentrent sur l'apport de méthodes à la fois accessibles et acceptables.

Author contact: eseiber@cph.osu.edu 